\title{
目標管理における目標の活性化の効果
}

\author{
新井田 恵美 $^{1}$ 東洋大学 $^{2}$
}

\section{Effect of goal activation on goal management}

Emi Niida (Toyo University)

\begin{abstract}
Studies of goal management have examined how to manage multiple goals. Previous research (Finkelstein \& Fishbach, 2010) showed that healthy eating made one hungrier. This study hypothesized that participants were hungrier when a health goal was not activated than when it was activated. It is expected that in such cases, goal shifting might be more likely to occur because goal progress had been perceived. Two experiments were conducted and their results were in line with this hypothesis. Participants reported being hungrier when their health goal were not activated than when these goals were activated. We consider the effect of goal activation on goal management and its implications for future research.
\end{abstract}

Key words: goal management, goal activation, goal progress, goal shifting.

The Japanese Journal of Psychology

2015, Vol. 86, No. 1, pp. 49-54

J-STAGE Advanced published date: March 13, 2015, doi.org/10.4992/jjpsy.86.13310

私たちは様々な目標をもち，意識的あるいは非意識 的に，それらの目標を達成しょうとしている。しかし ながら多くの場合，複数の目標を同時に追求すること は難しい。例えば勉強をしながら遊ぶことは多くの人 にとって困難だといえる。そのため，できる限り多く の目標を達成しょうとするには，それらの目標をうま くやり繰りする必要が生じる。こうした目標のやり繰 りは目標管理 (goal management) とよばれ, 近年, その心的メカニズムに関心が寄せられている。

目標管理に関する研究は主として, Shah (2005) な ど，ある目標を追求するとき，他の目標がどのように してその追求を妨害しないようにするか，ということ を問題としてきた。その結果，ある目標が活性化する と, 他の目標は抑制されたり (Shah, Friedman, \& Kruglanski, 2002)，ネガティブに評価されたりする (Myrseth, Fishbach, \& Trope, 2009) ことが示されてい る。一般に，抑制された目標やネガティブに評価され た目標は追求されにくいと考えられるため,こうした

Correspondence concerning this article should be sent to: Emi Niida, Graduate School of Sociology,Toyo University, Hakusan, Bunkyo-ku, Tokyo 112-8606, Japan (e-mail: emime8@gmail.com)

実験の実施および論文の執筆にあたり，樋口収先生（北海 道教育大学), 堀毛一也先生 (東洋大学) にお世話になりました。 ここに記して感謝申し上げます。
メカニズムは目標管理をする上で有益なメカニズムと いえる。

それに対して, 本論文ではもう1つの目標管理メカ ニズムに焦点をあてたい。すなわち，ある目標を追求 した後, 他の目標は, 改めて追求されるようになるの か, という問題である。抑制された, あるいはネガティ ブに評価された目標もまた追求するべき重要な目標で あることを考えれば，そうした目標をそのままの状態 にしておくことは目標管理上決して有益なメカニズム とはいえないと思われる。けれども，実際にこの点に ついて検討したものは数少ない。本研究では, 以下で 述べるように, ある目標を追求した後の目標管理に焦 点をあてる。

\section{目標追求後の目標管理}

複数ある目標をできる限り達成しょうとするなら ば, ある目標を追求する際, その目標追求の妨害とな らないよう抑制あるいはネガティブに評価していた目 標を追求できる状態にする必要がある。例えば Carver \& Scheier（1998）は, “ある目標が進展したと知覚さ れれば, 他の目標追求にシフトしやすいように, 進展 した目標に対する努力を弱める”と主張している (Frijda, 1994)。

ただし，著者の知る限り，こうした目標管理に関す る実証研究はほとんどない。数少ない研究の 1 つとし 
て Finkelstein \& Fishbach（2010）の報告がある。この 研究では健康的な食べ物を食べるという目標と好きな 物を自由に食べるという目標は葛藤を引き起こすとい う知見 (Herman \& Polivy, 1975; Muraven \& Baumeister, 2000）にもとづき，健康的な食べ物を食べた後，好き な物を自由に食べるという目標が追求されるかどうか を検討している。具体的には，一方の参加者には“健 康的なバー”，もう一方の参加者には“甘くて美味し いバー”と説明し，そのバーを食べてもらった後，参 加者に現在の空腹感について尋ねている（この空腹感 が好きなものを自由に食べるという目標の指標であっ た）。その結果, 同じバーを食べているにもかかわらず, 健康的なバーと説明された参加者はそうではない参加 者に比べて空腹感が高まることが示された。

Finkelstein \& Fishbach（2010）の実験は，ある目標 を追求した後の目標管理に焦点をあてているという意 味で非常に興味深い。しかしながら“健康的なバー” を 1 本食べただけでは，充分な栄養をとることはでき ないため, なぜ健康目標が進展したと知覚したのか, 明らかではない。本論文ではこの点について, 目標の 進展の知覚が生じるプロセスから考えてみたい。

\section{目標の進展を知覚するメカニズム}

一般に目標の進展の知覚は目標追求のプロセスで生 じるとされる (Carver \& Scheier, 1982)。目標追求はま ず目標（基準ともよばれる）が設定されて始まる。目 標が設定されると，その目標と現状（actual state）と の比較が行われる(モニタリングとよばれる)。そして, 目標と現状との間に乘離がなくなれば目標が進展した と知覚され，その目標への努力を弱めることになる。 一方，乘離があれば現状を目標に近づけるように動機 づけが高まる。

目標の進展の知覚が目標と現状とのモニタリングに よって生じるならば，目標や現状が正確に評価できな ければ, 目標の進展の知覚は正確なものではなくなる といえる。この点に関連して Liberman \& Dar(2009) は, 目標がなかったり，抽象的な場合には，具体的な場合 よりも正確にモニタリングをすることは難しく，目標 の進展は主観的な評価となりやすいと主張している。 このことを本研究の文脈で捉えると,「毎日野菜を食 べる」といった具体的な目標を設定したときの方が, 目標がなかったり，「健康になる」といった抽象的な 目標を設定したときよりもモニタリングは容易にな り, 結果として目標の進展を正確に知覚しやすいとい える。

ここで改めて Finkelstein \& Fishbach（2010）の実験 について考えてみると, この実験に参加していた参加 者は（甘い）バーを 1 本食べただけで, 健康目標が達 成できたと知覚し目標をシフトさせていたが，これは 目標が設定されていなかったために，正確にモニタリ
ングを行うことができなかった結果と考えれば解釈可 能である。実際, この研究では参加者は味見をして欲 しいと依頼されただけであり，健康目標の操作などは 一切扢こなわれておらず，目標が設定されていなかっ た可能性は十二分にある。

もしこの想定が正しいのであれば，健康目標が設定 され，正確なモニタリングが行われれば，空腹感が高 まらないことが予測される。そこで, 本研究は健康目 標の活性化を操作し, 目標の活性化が空腹感に及ほす 影響を検討する。

\section{実験の概要}

本研究は 2 つの実験を実施し, 健康目標の活性化が 目標の進展の知覚や空腹感に及ぼす影響を検討する。 これまでの議論から，本研究では，健康的な飲料を非 常に少量飲んだだけであっても，健康目標が活性化し ていない場合には, 誤って健康目標が進展したと知覚 しやすく，そのため健康目標からのシフトが生じ，空 腹感が高まると想定する。

実験 1 ではまず，ごく少量の健康飲料を飲んだとき でも，健康目標が活性化していなければ，誤って健康 目標が進展したと知覚されやすくなるかどうかを検討 する。実験 2 では, ごく少量の健康飲料を飲んだとき でも, 健康目標が活性化していなければ，空腹感が高 まるかどうかを検討する。

\section{実 験 1}

実験 1 では，健康目標の活性化が健康目標の進展の 知覚に及ぼす影響を検討する。目標が活性化していな い場合には正確なモニタリングが行なわれないため, 誤って目標が進展したと知覚することが考えられる。 実験 1 では，参加者に健康飲料あるいは（それと同力 ロリーの）甘い飲料を，ごく少量飲んでもらった後， 健康目標がどのくらい進展したと思うかを尋ねた。な お，健康目標の活性化の程度は個人差（慢性的アクセ シビリティ）によって測定する。すなわち，日常的に 野菜を摂るように気をつけている人ほど, “毎日野菜 をとる”という（具体的な）健康目標が慢性的に活性 化しているため，正確なモニタリングを行いやすいと 考えられる。そこで, 実験 1 では健康目標の活性化の 指標として，日常的にどのくらい注意して野菜を摂っ ているかを尋ねた。

仮説は次のと抢りである。ごく少量の健康飲料を飲 んだ人（健康飲料条件）は，同量の甘い飲料を飲んた 人 (非健康飲料条件) に比べて健康目標が進展したと 知覚するだろう。ただし，この傾向は健康目標が慢性 的に活性化していない人に限られるだろう。

\section{方 法}

参加者 大学生 54 名（男性 30 名, 女性 24 名, 平 
均年齢 20.46歳)であった。なお参加者は健康飲料条件, 非健康飲料条件にランダムに割り当て，それぞれ 27 名ずつとなった。

手続き 参加者には“新奇な飲み物, 食べ物に対す る好みの研究”と説明し, 飲み物, 食べ物をそれぞれ とった後, 感想に回答してもらうと説明した。その後, まず参加者に, 現在の気分, 今日の体調，および現在 の喉の渇き具合について，それぞれ 1 項目 7 件法で回 答を求めた。

喉の渴き具合について尋ねた後，半数の参加者には “野菜ジュースに飲むヨーグルトを少量混ぜた飲み物” を(健康飲料条件), 残りの半数の参加者には“ミル クティーに飲むヨーグルトを少量混ぜた飲み物”（非 健康飲料条件）を透明のカップに $110 \mathrm{ml}$ 入れて配布 した(なおいずれの飲み物も $36 \mathrm{kcal} / 100 \mathrm{ml}$ であった)。 配布後，参加者に飲み物に対してアレルギーをもつ者 がいないかどうかを確認した。該当者がいないことを 確認した後, 参加者に飲み物を飲むように教示した。 参加者が飲み物を飲んだことを確認した後, 現在の気 分（1 項目）や飲み物の印象（3 項目）について7 件 法で回答を求めた。

その後, 参加者には実際の実験はこれで終了であり, 食べ物に関する研究は行わないと説明し，謝罪した。 その上で，デブリーフィングに入る前にいくつかの項 目に回答して欲しいと依頼し，まず実験の（真の）目 的について自由記述をしてもらった。その後, 日頃の 食生活に関する質問 4 項目に 7 件法で回答してもらっ た。なお，この項目の中に，慢性的な健康目標の活性 化を尋ねる項目（“毎日野菜を食べるように気をつけ ている”)，および健康目標の進展の知覚を尋ねる項目 （“今日この後, 野菜を食べるつもりだ”）がそれぞれ 1 項目含まれていた（野菜をとるつもりがないほど, 健康目標が進展したと知覚していると考えられる)。 これらの質問に回答した後, 参加者に実験の真の目的 について説明し，実験参加の謝意を伝え，解散した。 なお，実験の真の目的に気づいていた参加者はいな かった。

\section{結 果}

実験 1 の仮説は，健康目標が日常的に活性化してい ない参加者がごく少量の健康飲料を飲んだ場合, 誤っ て健康目標が進展したと知覚するだろう，というもの である。

分析に先立ち, 以下のようなデータの整理を行った。 まず健康目標の活性化に関する個人差得点 $(M=4.46$; $S D=1.81 ）$ をセタリングした。次に健康飲料条件を +1 , 非健康飲料条件を -1 とダミー変数化した。そし て最後にこれらの項目の積の項を求めた。

仮説を検討するために, 上記の 3 項目を独立変数, 健康目標の進展の知覚に関する項目（“今日この後,
野菜を食べるつもりだ”）を従属変数とする一般線形 モデルによる分析を行った。その結果, 健康目標の活 性化の主効果が有意であった $(F(1,50)=19.74, p$ $<.01)$ 。ただしこの主効果は, 活性化 $\times$ 飲料の交互作 用効果によって調整されていた $(F(1,50)=6.77, p$ <.05) (Figure 1)。そこで下位検定を行ったところ, 健康飲料条件では, 健康目標が慢性的に活性化してい ない人たち $(-1 S D)$ は活性化している人たち $(+1 S D)$ に比べて，この後野菜を食べようとは思わなくなって いた $(F(1,50)=27.66, p<.01)$ 。すなわち, 健康目 標が活性化していない人たちは，健康目標が進展した と知覚しやすいことが示唆された。一方, 非健康飲料 条件では, 健康目標の活性化の程度によって健康目標 の進展の知覚に差異はみられなかった $(F(1,50)=$ $1.54, n s)$ 。

また，健康目標の活性化の程度（ $\pm 1 S D$ の地点） ごとに条件の効果を検討したところ，慢性的に活性化 していない人たち $(-1 S D)$ では，健康飲料条件の方 が非健康飲料条件よりも野菜を食べるつもりがなく なっていた $(F(1,50)=4.34, p<.05)$ 。なわち，健 康目標が相対的に活性化していない人が健康飲料を飲 むと, 健康目標が進展したと知覚しやすいことが示唆 された。一方, 活性化している人たち（+1SD）では, 条件によって健康目標の進展の知覚に差異はみられな かった $(F(1,50)=2.65, n s)$ 。

\section{考察}

実験 1 の結果，健康目標が慢性的に活性化していな い健康飲料条件の参加者は，他の参加者と比べて，野 菜を摂る意図が低くなっていた。この結果は本研究の 仮説を支持するものであり，健康目標が活性化してい ないときに健康的なものをごく少量でも摂ってしまう と, 誤って健康目標が進展したと知覚する可能性があ ることを示唆している。

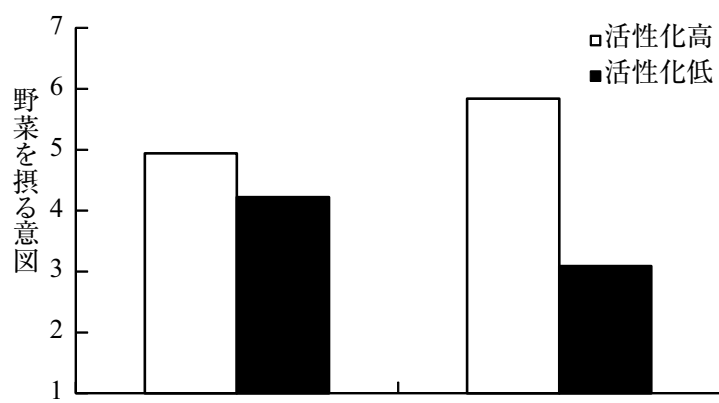

非健康飲料

健康飲料

Figure 1. 野菜を摂る意図の予測值

注）野菜を攝る意図は, 健康目標の進展の知覚の指標である。 野菜を摂る意図が高いほど, 目標が進展していないと知覚し ていることを意味している。 
ただし，この結果にはいくつか限界がある。まず， 本研究では健康目標の活性化の指標として個人差を用 いていたため, 健康目標の活性化と目標の進展の知覚 の因果関係が示されたわけではない。加えて, 本研究 では空腹感を尋ねていないため, 健康目標が進展した と知覚したとしても, 健康目標からのシフトが生じ, 空腹感が高まるかどうか定かではない。そこで, 実験 2 では健康目標の活性化を実験的に操作し, さらに健 康的な飲料を飲んだ後の空腹感を尋ねることとする。

\section{実 験 2}

実験 2 では健康目標の活性化を操作し，それが空腹 感に及ぼす影響を検討する。なお，目標の活性化の操 作は先行研究 (Koehler \& Poon, 2006; Zhang \& Fishbach, 2010）に倣い，空腹感を測定する前あるいは後に健康 目標に関する質問項目を尋ねることで行う。

仮説は次のとおりである。健康飲料を飲んだ人（健 康飲料条件）は，甘い飲料を飲んだ人（非健康飲料条 件）に比べて空腹感が高まるだろう。ただし，その傾 向は健康目標が活性化していない場合に限られるだろ う。

\section{方 法}

参加者 大学生 54 名（男性 25 名, 女性 29 名, 平 均年齢 19.44 歳）であった。な抬参加者は各条件にラ ンダムに割り当てられた。その結果, 健康飲料・目標 活性化条件 15 名, 健康飲料·目標非活性化条件 10 名, 非健康飲料・目標活性化条件 15 名, 非健康飲料 · 目 標非活性化条件 14 名となった。

手続き 参加者には実験 1 と同様に, “新奇な飲み 物, 食べ物に対する好みの研究” と説明し, 飲み物, 食べ物をそれぞれ摂った後, 感想に回答してもらうと 説明した。その後，まず半数の参加者にだけ（目標活 性化条件), 日頃の食生活に関する質問 9 項目に 7 件 法で回答してもらった。この項目の中には, 実験 1 で 健康目標の活性化の指標として用いた 1 項目に, 2 項 目加えた計 3 項目を含めた（“毎日野菜を食べるよう に気をつけている”, “毎日野菜を摂ることは重要だと 思う”, “何を食べるにせよ，栄養のバランスはきちん と考える”)。なお，残りの半数の参加者（目標非活性 化条件) は, 実験の最後にこれらの項目に回答した (残 りの 6 項目は，例えば “新商品は試してみたくなるほ うだ”などのフィラー項目であった)。

続けて, すべての参加者に, 現在の気分, 今日の体 調，および現在の喉の渴き具合について，それぞれ 1 項目 7 件法で回答を求めた。その後, 半数の参加者に は“野菜ジュースに飲むヨーグルトを少量混ぜた飲み 物”を(健康飲料条件), 残りの半数の参加者には “ミ ルクティーに飲むヨーグルトを少量混ぜた飲み物” (非 健康飲料条件）を透明のカップに $110 \mathrm{ml}$ 入れて配布
した。配布後，参加者に飲み物に対してアレルギーを もつ者がいないかどうかを確認した。該当者がいない ことを確認した後, 参加者に飲み物を飲むように教示 した。参加者が飲み物を飲んだことを確認した後, 現 在の気分 (1 項目) や飲み物の印象 (3 項目)につい て 7 件法で回答を求めた。その後, 参加者には, 今度 は新奇な食べ物を食べてもらうが，その前に現在の感 について回答して欲しいと伝え, 空腹感 (“今, お腹 が空いている”）を 1 項目 7 件法で尋ねた（この項目 が本実験の従属変数である)。

全員が回答したのを確認した後，参加者には実際の 実験はこれで終了であり, 食べ物に関する研究は行わ ないと説明し, 謝罪した。その上で, デブリーフィン グに入る前にいくつかの項目に回答して欲しいと依頼 し，まず実験の真の目的について自由記述をしても らった。その後, 参加者に実験の真の目的について説 明し, 実験参加の謝意を伝え, 解散した。なお，実験 の真の目的に気づいた参加者は一人もいなかった。

\section{結 果}

実験 2 の仮説は, 健康飲料・目標非活性化条件の参 加者のみが空腹感が高まるというものである。

この仮説を検討するため, 空腹感の程度を従属変数 とした2（目標の活性化: 有 vs. 無） $\times 2$ (飲料: 健康 飲料 vs. 非健康飲料) の分散分析を行った。その結果, 目標活性化の主効果が有意であった $(F(1,50)=4.30$, $p<.05)$ 。ただし，この主効果は活性化 $\times$ 飲料の交互 作用効果によって調整されていた $(F(1,50)=4.61, p$ $<.05)$ (Figure 2)。そこで飲料条件で単純主効果検定 を行ったところ, 健康飲料条件で活性化の単純主効果 が有意であり $(F(1,50)=8.14, p<.01)$, 目標非活性 化条件 $(M=4.80)$ の方が目標活性化条件 $(M=3.13)$ よりも空腹感が高まっていた。一方, 非健康飲料条件 ではそのような差はみられなかった（ $M=3.57$ vs. $M=$ $3.60 ; F(1,50)<1, n s)$ 。

同様に, 活性化条件で単純主効果検定を行ったとこ

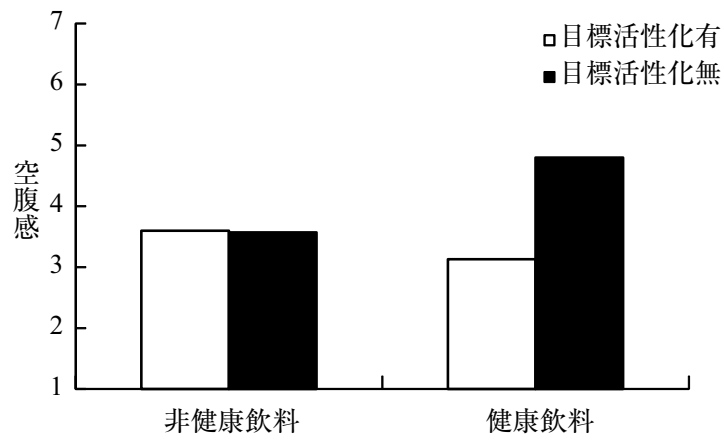

Figure 2. 各条件ごとの空腹感の平均值

注）得点範囲は 1 -7である。 
ろ, 目標非活性化条件で飲料の主効果が有意であり, 健康飲料条件の方が非健康飲料条件よりも空腹感が高 まることが示された $(F(1,50)=4.30, p<.05)$ 。一方, 目標活性化条件ではそのような差はみられなかった $(F(1,50)<1, n s)$ 。

\section{考察}

実験 2 では，健康目標の活性化を操作し，それが空 腹感, すなわち目標のシフトに及ぼす影響を検討した。 実験の結果，健康目標が活性化していない場合に，ご く少量の健康飲料を飲むと空腹感が高まっていた。こ の結果は仮説を支持していた。

\section{総合考察}

本研究は, 目標の活性化が目標追求後の目標管理に 及ぼす影響，すなわち，ある目標が進展したと知覚さ れた場合に他の目標へとシフトするかどうかを検討し た。目標が活性化していない場合にはモニタリングが 不正確になるため, 本来は目標が進展したと知覚でき ないような場合でも目標が進展したと知覚しやすく， 目標がシフトするかどうかを検討した。

実験 1 では，日常的に健康目標が活性化していない 参加者がごく少量の健康飲料を飲んだ場合に，健康的 なものを摂ろうとする意眓が下がっており，健康目標 が進展したと誤って知覚したことが示唆された。実験 2 では, 健康目標の活性化を操作したところ, 健康目 標非活性化条件において，ごく少量の健康飲料を飲ん だ参加者は空腹感が高まっており, 健康目標からのシ フトが生じたことが示唆された。この結果は本研究の 仮説を支持するものであった。

本研究では目標追求のプロセスに注目し，モニタリ ングが不正確な場合には誤った目標のシフトが生じる 可能性を示した。すなわち, 本研究はFinkelstein \& Fishbach (2010) の研究では十分に検討されていなかっ た目標のシフトのプロセスの一端を示し，また目標の シフトがときに誤って生じることを示した。これらの 点は, これまでの研究では明らかにされていなかった 点であり，本研究の成果といえるだろう。

このように本研究は一定の成果を収めたものの，代 替説明も考えられる。例えば, 目標が活性化していな い場合は目標が活性化している場合に比べて基準が低 くなり，そのため目標の進展を知覚しやすかったとい う可能性がある。ただし, 本研究で参加者が飲んだ飲 料の量はごく微量の $110 \mathrm{ml}$ であり, この程度ではい くら基準が低かったとしても，その基準を満たしたと は考えにくい。そのため, 本研究の結果については, 基準が低かったために目標が進展したと知覚しやす かったと解釈するよりも，モニタリングが曖昧になっ たと解釈する方が妥当なように思われる。しかしなが ら,このことは基準の高さが目標の進展の知覚と関係
しないということを意味するわけではない。そのため, 目標の高さと目標のシフトの関係については, 今後検 討していく必要がある。

また,この他にも重要な課題が残っている。目標追 求後の目標管理（目標のシフト）に関する研究はこれ までのところ研究数が非常に少なく，これから多くの 研究を積み重ねていく必要がある。すなわち, 多くの 異なる健康目標の活性化の操作（Bargh, Gollwitzer, Lee-Chai, Barndollar, \& Troetschel, 2001） や空腹感以外 の従属変数を測定し, 研究をリプリケイトしていく必 要がある。加えて, こうした目標のシフトが健康目標 以外の目標においてもみられるかどうかなども検討し ていく必要があるだろう。

私たちは多くの目標を抱え，限られた時間の中でそ れらをできる限り達成したいと願っており，効率よく 目標追求をしていくことが求められる。そのような意 味でも，いかにうまく目標をやり繰りするかは重要な 問題であり，本研究で扱った目標管理は研究上重要な だけでなく，日常生活においても重要な問題でもある といえるだろう。

\section{引用文献}

Bargh, J. A., Gollwitzer, P. M., Lee-Chai, A., Barndollar, K., \& Troetschel, R. (2001). The automated will: Nonconscious activation and pursuit of behavioral goals. Journal of Personality and Social Psychology, 81, 1014-1027.

Carver, C. S., \& Scheier, M. F. (1982). Control theory:A useful conceptual framework for personality-social, clinical and health psychology. Psychological Bulletin, 92, 111-135.

Carver, C. S., \& Scheier, M. F. (1998). On the self-regulation of behavior. New York: Cambridge University Press.

Finkelstein, S. R., \& Fishbach, A. (2010). When healthy food makes you hungry. Journal of Consumer Research, 37, 357-367.

Frijda, N. H. (1994). Emotions are functional, most of the time. In P. Ekman \& R. J. Davidson (Eds.), The nature of emotion: Fundamental questions. New York: Oxford University Press. pp. 112-126.

Herman, C. P., \& Polivy, J. (1975). Anxiety, restraint, and eating behavior. Journal of Abnormal Psychology, 84, 666-672.

Koehler, D. J., \& Poon, C. S. K. (2006). Self-predictions overweight strength of current intentions. Journal of Experimental Social Psychology, 42, 517-524.

Liberman, N., \& Dar, R. (2009). Normal and pathological consequences of encountering difficulties in goals. In G. B. Moskowitz \& H. Grant (Eds.), The psychology of goals. New York: Guilford Press. pp. 277-303.

Muraven, M., \& Baumeister, R. F. (2000). Self-regulation and depletion of limited resources: Does self-control 
resembl a muscle? Psychological Bulletin, 126, 247259.

Myrseth, K. O. R., Fishbach, A., \& Trope, Y. (2009). Counteractive self-control: When making temptation available makes temptation less tempting. Psychological Science, 20, 159-163.

Shah, J. Y. (2005). Automatic pursuit and management of goals. Current Directions in Psychological Science, 14, 10-13.
Shah, J. Y., Friedman, R., \& Kruglanski, A. W. (2002). Forgetting all else: On the antecedents and consequences of goal shielding. Journal of Personality and Social Psychology, 83, 1261-1280.

Zhang, Y., \& Fishbach, A. (2010). Counteracting obstacles with optimistic predictions. Journal of Experimental Psychology: General, 139, 16-31.

2013. 7.22 受稿, 2014. 11.8 受理 